\title{
Phytochemical Analysis of Two Cytotypes (2x and 4x) of Physalis angulata an Important Medicinal Plant, Collected from Rajasthan
}

\section{Ramanpreet Brar* and Raghbir Chand Gupta}

Department of Botany Punjabi University, Patiala, Punjab, India

${ }^{*}$ Corresponding author: Ramanpreet Brar, Department of Botany Punjabi University, Patiala, Punjab, Inida, Tel: +919914446900; E-mail: ramanbrar247@gmail.com

Received Date: September 25, 2017; Accepted date: October 13, 2017; Published date: October 18, 2017

Citation: Brar R, Gupta RC (2017) Phytochemical analysis of two cytotypes (2x \& 4x) of Physalis angulata an important medicinal plant, collected from Rajasthan. Biochem Mol Biol J Vol. 3: No. 3:15.

\section{Abstract}

A simple, selective, sensitive and precise high performance thin layer chromatographic technique was followed to determine the diversity within two cytotypes of $P$. angulata. Fruit, stem, leaf and root samples extracted in $n$-hexane were used to quantify phenols and phytosterols and methanolic extracts for triterpinoids. The amounts of phytochemical differ in both the cytotypes of the same species.

\section{Keywords: Physalis angulate; Antiseptic; Cosmetic} industry

\section{Introduction}

Medicinal plants contain various bioactive compounds used for curing many human diseases. These bioactive compounds or phytochemicals are characterized in two groups primary and secondary. Primary constituents are proteins, chlorophyll, sugars and amino acids and secondary ones are terpenoids (group of lipids) phenolic compounds (derived from carbohydrates) and alkaloids (derived from amino acids).

Physalis angulata belongs to family Solanaceae and is medicinally very important plant. In some countries the species is used as traditional medicine since pre-Columbian times [1]. The plant is used to treat several diseases such as asthma [2], hepatitis [2,3], malaria [2], boil, liver problem, diuretic and its extract have antiviral, anti-inflammatory, antimicrobial, antiseptic, diuretic, anticancer, antitumor, antimycobacterial, immunosuppresion properties. All the plant parts of the herb are used for its medical value [4-7]. Like antinociceptive properties were first recognized for roots [7] and stem [8]. However, leaves are associated with cytoxcity against murine luekemia cell line P-388, epidermoid carcinoma of the nasopharyx KB-16 cells and lung adenocarcinoma A-549 [9].

There are many phytochemical techniques used for the separation of biochemical from medicinal plants such as Paper chromatography, Column Chromatography, Thin Layer
Chromatography, High Performance Liquid Chromatography, High Performance Thin Layer Chromatography and Gas Chromatography coupled with Mass Spectroscopy, to mention few. The quality and quantity of secondary metabolities in plants vary with different environmental conditions, soil conditions and altitude. Besides, this other factor like morphological variation, different ploidy levels and cytological irregularities also play a key role in variation of bioactive compounds in plants. The main objective of the present study is to compare the amount of specific phytochemicals in different plant parts of cytotype.

\section{Material and Methods}

For the acquisition, a CAMAG HPTLC system comprising a Linomat-V automatic sample applicator and CAMAG TLC Scanner III with win CATS software was used. For the reflectance/absorbance mode deuterium and halogen tungsten lamp is used with high pressure mercury lamp as reflectance/fluorescence mode. A CAMAG $100 \mu \mathrm{L}$ precision syringe from Hamilton, Bonaduz, Switzerland was used for sample application under gentle stream of nitrogen. CAMAG aluminium per-coated silica gel plates were used. Silica gel 60F254 plates with $200 \mu \mathrm{m}$ thickness $\times 5 \mu \mathrm{m}$ particle sizes from Merck, Dermostst, Germany were used. For the plate development a CAMAG twin-trough chamber $20 \mathrm{cmW} \times 10$ $\mathrm{cmH}$ was used. The plate was left in pre-heated oven at $105^{\circ} \mathrm{C}$ for 5 mins. Violet color spots of the standard and the samples appear. The densitometry chromatographs of the plates were taken at different wavelength. Anisaldehyde sulfuric acid was prepared by dissolving, $5 \mathrm{ml}$ of anisaldehyde solution in $1 \mathrm{ml}$ of $98 \%$ sulfuric acid and $50 \mathrm{ml}$ of acetic acid.

After development and derivatization of the plate, measurements were made by winCATS software. Concentration of the target analytes in the separated bands were determined from the intensity of the reflected light indicated and the peak areas produced were correlated to the analyte concentrations using six level linear calibration curves. The employed statistical analysis ensures that the developed method is reproducible and selective. This method can be used as an important tool to ensure the therapeutic dose in herbal formulations, standardization and quality control of bulk drugs. 
The significant difference between the amounts of particular compound in each plant is also mentioned in the table.

\section{Sample Preparation}

Aerial parts of the plants were extracted with methanol by using Soxhlet apparatus. The plant material was shade dried and coarsely powdered before Soxhlet apparatus application. $10 \mathrm{~g}$ of each dried and powdered aerial plant parts was applied to the methanolic extraction independently in Soxhlet apparatus. The extracts were concentrated using rota- evaporator and then lypholyzed. Powdered extracts was weighed and $5 \mathrm{mg}$ of each was dissolved in $5 \mathrm{ml}$ of methanol to obtain $1 \mathrm{mg} / 1 \mathrm{ml}$ concentration.

\section{Results and Discussion}

HPTLC methods were used to estimate the composition of quercetin, lupeol, ursolic acid, $\beta$-sitosterol, campesterol, withaferine $A$, withanolide $A$, withanolide $B$ and emodin of different plant parts (fruit, stem, leaf, root) in two cytotypes ( $2 x$ and $4 x$ ) of $P$. angulata, by using different mobile phases respective for each bioactive compound (Table 1 ).

Table 1 Part-based HPTLC analysis of active phyto-constituents in two cytotypes (2x, 4x) of $P$. angulata.

\begin{tabular}{|c|c|c|c|c|c|c|}
\hline \multirow{2}{*}{$\begin{array}{l}\text { Reference } \\
\text { Compound/Part } \\
\text { Plant }\end{array}$} & Mean $(\mu \mathrm{g} / \mathrm{mg})$ & SD & Mean $(\mu \mathrm{g} / \mathrm{mg})$ & SD & \multirow[t]{2}{*}{ Significance } & \multirow[t]{2}{*}{ P-value } \\
\hline & \multicolumn{2}{|l|}{$\begin{array}{l}\text { Diploid cytotype } \\
(2 x)\end{array}$} & \multicolumn{2}{|c|}{$\begin{array}{l}\text { Tetraploid Cytotype } \\
(4 x)\end{array}$} & & \\
\hline \multicolumn{7}{|c|}{ Querectin } \\
\hline Fruit & 0 & 0 & 0 & 0 & - & - \\
\hline Stem & 0.04 & 0.01 & 3.67 & 0.03 & Yes & $<0.001$ \\
\hline Leaves & 0 & 0 & 14.28 & 0.024 & Yes & $<0.001$ \\
\hline Root & 0 & 0 & 0 & 0 & & \\
\hline \multicolumn{7}{|c|}{ Lupeol } \\
\hline Fruit & 26.78 & 0.028 & 23.93 & 0.16 & Yes & $<0.001$ \\
\hline Stem & 0.65 & 0.01 & 0.44 & 0.18 & Yes & $<0.001$ \\
\hline Leaves & 2.94 & 0.02 & 5.42 & 0.44 & Yes & $<0.001$ \\
\hline Root & 0.22 & 0.019 & 1.66 & 0.37 & Yes & $<0.001$ \\
\hline \multicolumn{7}{|c|}{ Ursolic acid } \\
\hline Fruit & 6.54 & 0.55 & 3.98 & 0.44 & Yes & $<0.001$ \\
\hline Stem & 3.74 & 0.73 & 13.19 & 0.24 & Yes & $<0.001$ \\
\hline Leaves & 9.18 & 0.78 & 3.52 & 0.38 & Yes & $<0.001$ \\
\hline Root & 3.92 & 0.62 & 2.81 & 0.28 & Yes & $<0.001$ \\
\hline \multicolumn{7}{|c|}{$\beta$-sitosterol } \\
\hline Fruit & 10.84 & 0.32 & 5.57 & 0.13 & Yes & $<0.001$ \\
\hline Stem & 11.57 & 0.36 & 0 & 0 & Yes & $<0.001$ \\
\hline Leaves & 4.95 & 0.60 & 16.60 & 0.26 & Yes & $<0.001$ \\
\hline Root & 11.94 & 0.39 & 12.26 & 0.52 & Yes & 0.001 \\
\hline \multicolumn{7}{|c|}{ Campesterol } \\
\hline Fruit & 2.82 & 0.13 & 5.22 & 0.42 & Yes & $<0.001$ \\
\hline Stem & 3.19 & 0.26 & 4.23 & 0.29 & Yes & $<0.001$ \\
\hline Leaves & 4.59 & 0.29 & 10.02 & 0.31 & Yes & $<0.001$ \\
\hline Root & 8.65 & 0.26 & 6.34 & 0.29 & Yes & $<0.001$ \\
\hline \multicolumn{7}{|c|}{ Withaferin A } \\
\hline Fruit & 24.67 & 0.37 & 5.27 & 0.45 & Yes & $<0.001$ \\
\hline
\end{tabular}




\begin{tabular}{|c|c|c|c|c|c|c|}
\hline Stem & 40.31 & 0.18 & 18.21 & 0.39 & Yes & $<0.001$ \\
\hline Leaves & 9.74 & 0.43 & 15.54 & 0.26 & Yes & $<0.001$ \\
\hline Root & 7.83 & 0.37 & 18.63 & 0.34 & Yes & $<0.001$ \\
\hline \multicolumn{7}{|c|}{ Wthanolide A } \\
\hline Fruit & 0.028 & 0.060 & 1.80 & 0.011 & Yes & $<0.001$ \\
\hline Stem & 0 & 0 & 0 & 0 & - & - \\
\hline Leaves & 4.12 & 0.036 & 11.03 & 0.080 & Yes & $<0.001$ \\
\hline Root & 4.75 & 0.054 & 11.33 & 0.050 & Yes & $<0.001$ \\
\hline \multicolumn{7}{|c|}{ Withanolide B } \\
\hline Fruit & 0 & 0 & 0 & 0 & - & - \\
\hline Stem & 0 & 0 & 2.67 & 0.30 & Yes & $<0.001$ \\
\hline Leaves & 0 & 0 & 7.22 & 0.13 & Yes & $<0.001$ \\
\hline Root & 0.170 & 0.10 & 0 & 0 & Yes & $<0.001$ \\
\hline \multicolumn{7}{|c|}{ Emodin } \\
\hline Fruit & 1.186 & 0.028 & 0.91 & 0.78 & No & 0.576 \\
\hline Stem & 1.12 & 0.97 & 0.39 & 0.34 & No & 0.290 \\
\hline \multirow[t]{2}{*}{ Leaves } & 0.62 & 0.54 & 5.92 & 0.39 & Yes & $<0.001$ \\
\hline & 0.57 & 0.50 & 2.67 & 0.44 & Yes & 0.006 \\
\hline
\end{tabular}

Appropriate amount of each standard as well as samples were applied to the 60 F254 silica gel plates. The plates were allowed to dry at the room temperature and then linear ascending development was carried out in pre- saturated twin chamber containing with particular mobile phase. After drying the plates were scanned. Phenolic compounds are plant secondary metabolites with wide spectrum of biological activities.

\section{Quercetin}

At present it is separated by using Toluene: Ethyl acetate: Formic acid: Methanol (7:5:.5:0.1 v/v/v/v) as mobile phase. The $R f$ value of the reference compound is reported to be at 0.63 (Figure 1). The maximum amount is found in the leaves of tetraploid cytotype $(14.28 \pm 0.024 \mu \mathrm{g} / \mathrm{mg}$ of DWE) of plant samples followed by its stem samples $(3.67 \pm 0.033 \mu \mathrm{g} / \mathrm{mg}$ of DWE). In the diploid cytotype, its occurrence is reported only in stem with very less amount $(0.040 \pm 0.001 \mu \mathrm{g} / \mathrm{mg}$ of DWE), (Figure 1), (Tables 1 and 2).

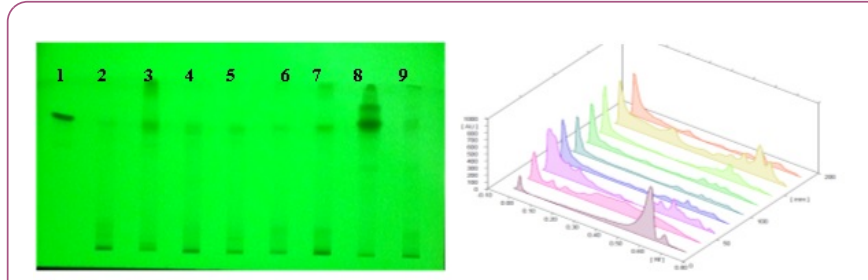

Figure 1 HPTLC fingerprint profile of quercetin (Track 1) in diploid (Track 2- fruit; 3-stem; 4- leaf; 5-root) and tetraploid (Track 6-fruit; 7-stem; 8-leaf; 9- root) cytotypes of $P$. angulata B) 3D view of densitogram at $254 \mathrm{~nm}$.

The amount of quercetin was found to be more in tetraploid cytotype as compared to the diploid cytotype, significant at $\mathrm{P}<0.001$ (Table 1).

Table 2 Data showing different parameters analyzed for the reference compounds.

\begin{tabular}{|c|c|c|c|c|c|c|c|c|c|}
\hline $\begin{array}{l}\text { Reference } \\
\text { compound }\end{array}$ & Quercetin & Lupeol & $\begin{array}{l}\text { Ursolic } \\
\text { acid }\end{array}$ & $\begin{array}{l}\beta- \\
\text { sitosterol }\end{array}$ & Campestrol & $\begin{array}{l}\text { Withaferin } \\
\text { A }\end{array}$ & $\begin{array}{l}\text { Withanolide } \\
\text { A }\end{array}$ & $\begin{array}{l}\text { Withanolide } \\
\text { B }\end{array}$ & Emodin \\
\hline $\begin{array}{l}\text { Working } \\
\text { concentration }\end{array}$ & $\begin{array}{l}2-10 \quad \mu g / \\
\text { Band }\end{array}$ & $\begin{array}{l}2-10 \mu g / \\
\text { Band }\end{array}$ & $\begin{array}{l}2-10 \mu \mathrm{g} / \\
\text { Band }\end{array}$ & $\begin{array}{l}2-10 \quad \mu g / \\
\text { Band }\end{array}$ & 2-10 $\mu \mathrm{g} / \mathrm{Band}$ & $\begin{array}{l}2-10 \quad \mu g / \\
\text { Band }\end{array}$ & 2-10 $\mu \mathrm{g} /$ Band & $2-10 \mu \mathrm{g} / \mathrm{Band}$ & $\begin{array}{l}2-10 \mu \mathrm{g} / \\
\text { Band }\end{array}$ \\
\hline Rf value & 0.63 & 0.84 & 0.36 & 0.64 & 0.74 & 0.81 & 0.45 & 0.64 & 0.89 \\
\hline
\end{tabular}




\begin{tabular}{|c|c|c|c|c|c|c|c|c|c|}
\hline $\begin{array}{l}\text { Regression } \\
\text { equation }\end{array}$ & $\begin{array}{l}Y=4590^{*} X \\
+2560\end{array}$ & $\begin{array}{l}Y= \\
2653^{*} X+ \\
1548\end{array}$ & $\begin{array}{l}Y= \\
924.3^{*} X- \\
155.1\end{array}=$ & $\begin{array}{l}Y \\
1308^{*} X+ \\
609.7\end{array}$ & $\begin{array}{l}Y=2554^{*} X+ \\
214.4\end{array}$ & $\begin{array}{l}Y=555.8^{\star} X \\
+307.8\end{array}$ & $\begin{array}{l}Y=470^{*} X+ \\
359.4\end{array}$ & $\begin{array}{l}Y=470^{*} X+ \\
319.4\end{array}$ & $\begin{array}{l}Y= \\
1795^{\star} X+ \\
674.1\end{array}$ \\
\hline $\begin{array}{l}\text { Correlation } \\
\text { coefficient (r2) }\end{array}$ & 0.996 & 0.998 & 0.997 & 0.995 & 0.993 & 0.998 & 0.996 & 0.995 & 0.997 \\
\hline LOD (ng) & 364 & 407 & 578 & 419 & 928 & 260 & 405 & 488 & 310 \\
\hline LOQ (ng) & 1100 & 1234 & 987 & 1272 & 2813 & 788 & 1228 & 1479 & 942 \\
\hline
\end{tabular}

It is the most common flavonol in fruits and green vegetables. Earlier, this compound was also reported in leaves of $P$. angulata [10]. There are many methods for the determination of flavonoids in different plants, but there is no such method developed for $P$. angulata.

\section{Triterpinoids}

Terpeniods have been derived from five carbon isoprene units. Most of these have multi-cyclic structure which differs from one another by their functional groups and basic carbon skeleton. Most of terpenoids are used as fragrances in food and cosmetic industry. These are wide spread in nature, mainly in plants as constituents of essential oils. Their building blocks are hydrocarbon isoprene and are classified according to the number of isoprene units. Triterpenes consists of six isoprene units.

\section{Lupeol}

It is separated by using Toluene: Methanol: Formic acid $(9: 4: 0.2 \mathrm{v} / \mathrm{v} / \mathrm{v})$ as mobile phase. The $\mathrm{R} f$ value of the reference compound is reported to be at 0.84 (Figure 2).

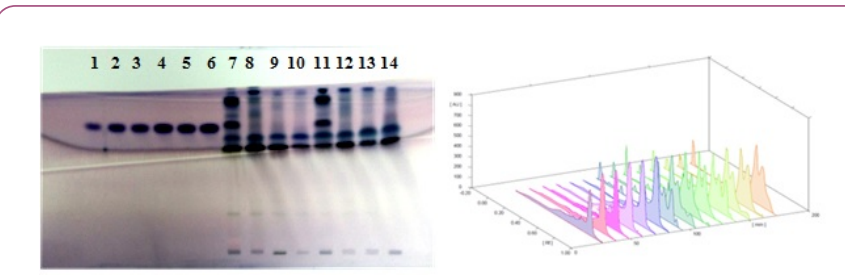

Figure 2 HPTLC fingerprint profile of lupeol (Track 1-6) in diploid (Track 7-fruit; 8-stem; 9-leaf; 10-root) and tetraploid (Track 11-fruit; 12- stem; 13-leaf; 14-root) cytotypes of P. angulata B) 3D view of densitogram at $530 \mathrm{~nm}$.

Lupeol is reported in good quantity in both the cytotypes. Fruits of both the cytotypes are very rich in lupeol content with maximum amount reported in the diploid fruits $(26.78 \pm$ $0.02 \mu \mathrm{g} / \mathrm{mg}$ of DWE), followed by the tetraploid fruit samples $(23.93 \pm 0.016 \mu \mathrm{g} / \mathrm{mg}$ of DWE), respectively. A good amount of this compound is also reported in leaves of the tetraploid cytotype (5.42 $\pm 0.044 \mu \mathrm{g} / \mathrm{mg}$ of DWE), (Table 1 and 2). The amount of lupeol was found to be more in the tetraploid cytotype as compared to the diploid cytotype, significant at $\mathrm{P}<0.001$ (Table 1). Lupeol has been investigated using HPTLC in many medicinal plants like Strobilanthus callosus [11,12], Acacia leucophloea [13], Abutilon indicum [14], Hygrphila auriculta [14], Acanthus ilicifolius [15], Neoalsomitra clavigera and in Derris heyneana [16].

\section{Ursolic acid}

A pentacyclic triterpenoid possess a wide range of pharmacological activities. It shows hypoglycemic, antibacterial, anti-inflammatory, antioxidant, diuretic and cynogenic activity. It is commonly present in plants especially coating of leaves and fruits, such as apple fruit, leaves of Vinca, rosemary, and eucalyptus.

Mixture of Toluene: Ethyl acetate: Formic acid (8:2:0.1 $\mathrm{v} / \mathrm{v} / \mathrm{v}$ ) was used as mobile phase to separate ursolic acid. The $\mathrm{Rf}$ value of the reference compound is reported to be 0.36 (Figure 3).

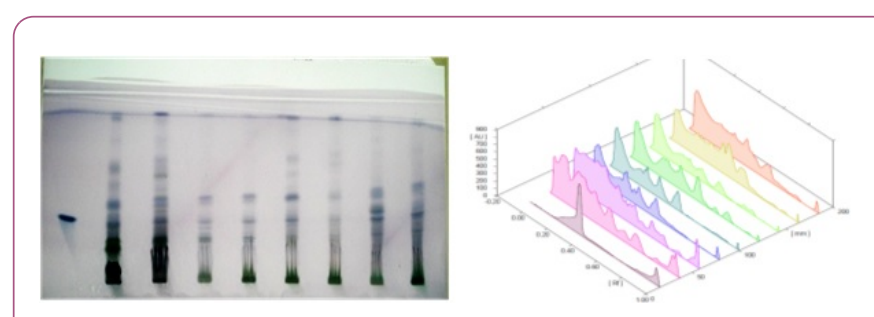

Figure 3 HPTLC fingerprint profile of ursolic acid (Track 1) in diploid (Track 2- fruit; 3-stem; 4-leaf; 5- root) and tetraploid (Track 6-fruit; 7-stem; 8-root; 9- root) cytotypes of $P$. angulata B) 3D view of densitogram at $510 \mathrm{~nm}$.

The maximum amount of ursolic acid is reported in the stem of the tetraploid cytotype (13.19 $\pm 0.024 \mu \mathrm{g} / \mathrm{mg}$ of DW) of plant samples followed by the diploid leaves $(9.18 \pm 0.078$ $\mu \mathrm{g} / \mathrm{mg}$ of DW) (Tables 1 and 2 ). The amount of ursolic acid was found to be more in the tetraploid cytotype as compared to the diploid cytotype, significant at $\mathrm{P}<0.001$ (Table 1 ).

\section{Phytosterols}

$\boldsymbol{\beta}$-sitosterol: $\beta$-sitosterol is used to cure heart diseases and fight high cholesterol levels in the body. It is also used to boost immune system. It helps in the prevention of influenza, cancer, different types of allergies, asthma, bronchitis, and migraine and hair loss.

A mixture of Toluene: Ethyl acetate in ratio of 9:4 (v/v). The Rf value was noticed at 0.64 (Figure 4). 


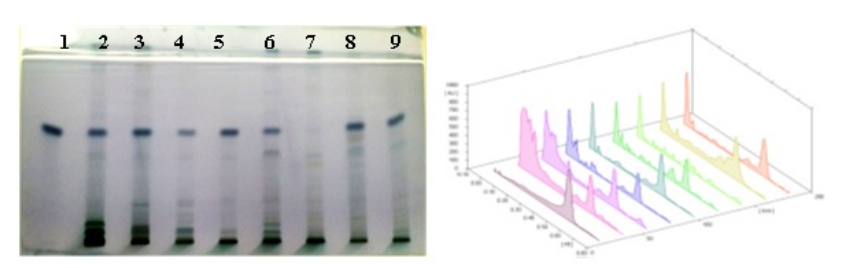

Figure 4 HPTLC fingerprint profile -sitosterol (Track 1) in diploid (Track 2fruit; 3-stem; 4leaf; 5root) and tetraploid (Track 6-fruit; 7stem; 8-leaf; 9-root) cytotypes of P. angulata B) $3 D$ view of densitogram at $530 \mathrm{~nm}$.

The highest amount is reported in leaf samples of the tetraploid cytotype $(16.6 \pm 0.26 \mu \mathrm{g} / \mathrm{mg}$ of DWE) followed by its root samples (12.26 $\pm 0.05 \mu \mathrm{g} / \mathrm{mg}$ of DWE) (Tables 1 and 2 ). The amount is almost same in stem and root samples of diploid cytotype.

The amount of $\beta$-sitosterol was found to be more in the tetraploid cytotype as compared to the diploid cytotype, significant at $\mathrm{P}<0.001$ (Table 1 ).

Campesterol: A mixture Toluene: Methanol: Formic acid in ratio 9:4:0.2 (v/v/v) is used to separate campesterol from other compounds. The $\mathrm{R} f$ value was noticed at 0.74 (Figure 5).

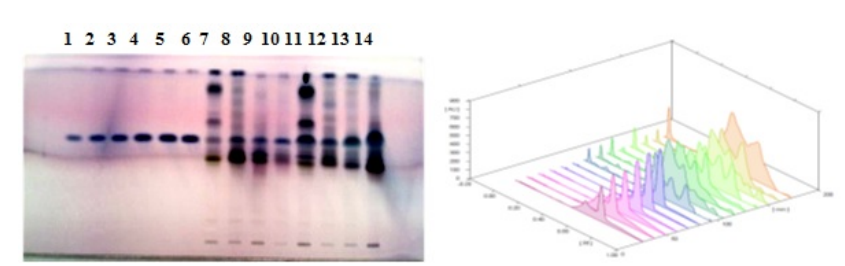

Figure 5 HPTLC fingerprint profile of campesterol (Track 1-6) in diploid (Track 6-fruit; 8-stem; 9-leaf; 10-root) and tetraploid (Track 11-Fruit; 12- stem; 13-leaf; 14-Root) cytotypes of $P$. angulata B) 3D view of densitogram at 530 $\mathrm{nm}$.

The reference compound was reported in leaf and root samples of both the cytotypes. But the maximum amount was reported in leaves samples of the tetraploid cytotype (10.82 \pm . $003 \mu \mathrm{g} / \mathrm{mg}$ of DWE) followed by roots samples of the diploid cytotype (8.65 $\pm 0.002 \mu \mathrm{g} / \mathrm{mg}$ of DWE) (Tables 1 and 2). The amount of campesterol was found to be more in the tetraploid cytotype as compared to the diploid cytotype, significant at $\mathrm{P}<0.001$ (Table 1).

Withaferin A: It is separated by using Toluene: Ethyl acetate: Formic: Ethanol (6:3:0.1:0.6 v/v/v/v) as mobile phase and $p$ anisaldehyde sulphuric acid as derivatizing reagent. The $\mathrm{Rf}$ values of the reference compound was 0.81. Maximum amount of withaferin $A$ is reported in the stem samples of the diploid cytotype $(40.31 \pm 0.018 \mu \mathrm{g} / \mathrm{mg}$ of $\mathrm{DW})$ of plant followed by its fruit samples $(24.67 \pm 0.03 \mu \mathrm{g} / \mathrm{mg}$ of DWE) (Tables 1 and 2). In the tetraploid cytotype stem samples and root samples contained almost same amount of the reference compound $(18.63 \pm 0.034 \mu \mathrm{g} / \mathrm{mg}$ and $18.21 \pm 0.039 \mu \mathrm{g} / \mathrm{mg}$ of DWE) respectively (Figure 6).
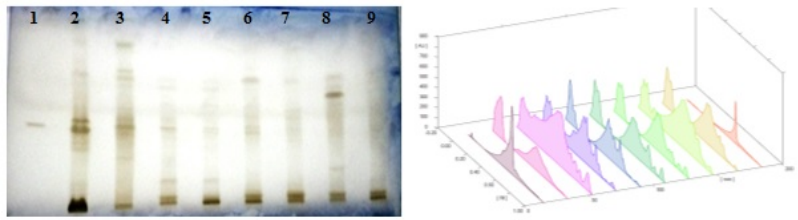

Figure 6 HPTLC fingerprint profile of withaferin A (Track 1) in diploid (Track 2-fruit; 3-stem; 4-leaf; 5-root) and tetraploid (Track 6-fruit; 7-stem; 8-leaf; 9-root) cytotypes of $P$. angulata B) 3D view of densitogram at $530 \mathrm{~nm}$.

The amount of withaferin A was found to be more in diploid cytotype as compared to tetraploid cytotype, significant at $\mathrm{P}<0.001$ (Table 1). In contrary to the present results which revealed the presence of most of the bioactive compound in tetraploid cytotype, the withaferin A, is reported to be more in the diploid cytotype than in the tetraploid cytotype.

Cancer, being the second leading cause of mortality, exists as a formidable health challenge. Withaferin- $A$, sensitizes resistant cancer cells to existing chemotherapeutic agents. The antioxidant activity of withaferin-A was first reported [17]. Previously, novel HPTLC method was developed [18-20] for the estimation of withaferin $A$ in for Withania somnifera. Withaferin-A was also estimated in polyherbal formulations [21]. The content of withanolide $A$ and withaferin $A$ were compared in two different morphotypes in different plant parts of Withania somnifera by using HPTLC method [22].

Withanolides (A and B): Withanolides possess potent antitumor and antioxidant properties. Same mobile phase used to separate both the withanolide and after derivatizing the $\mathrm{Rf}$ values of the compounds were 0.45 and 0.64 , respectively.

Leaf and root samples of the tetraploid cytotypes contained highest amount of withanolide A $(11.03 \pm 0.08 \mu \mathrm{g} / \mathrm{mg} \& 11.33$ $\pm 0.05 \mu \mathrm{g} / \mathrm{mg}$ DWE) respectively. In the diploid cytotype root samples and leaf samples contained more withanolide A (4.75 $\pm 0.054 \mu \mathrm{g} / \mathrm{mg}$ and $4.12 \pm 0.036 \mu \mathrm{g} / \mathrm{mg}$ DWE) respectively (Figure 7) (Tables 1 and 2).

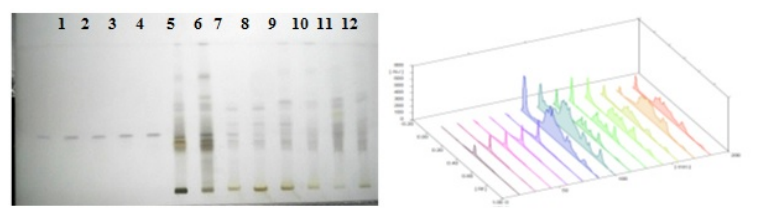

Figure 7 HPTLC fingerprint profile of withanolide A (Track 1-5) in diploid (Track 6-fruit; 7-stem; 8-leaf; 9-root) and tetraploid (Track 10-Fruit; 11-stem; 12-leaf; 13-Root) cytotypes of $P$. angulata B) 3D view of densitogram at 530 $\mathrm{nm}$.

Withanolide B: Withanolide B was completely absent in the diploid cytotype with very negligible amount in root sample 
$(0.170 \pm 0.001 \mu \mathrm{g} / \mathrm{mg})$. In the tetraploid cytotype the stem $(2.67 \pm 0.003 \mu \mathrm{g} / \mathrm{mg})$ and the leaf $(7.22 \pm 0.003 \mu \mathrm{g} / \mathrm{mg})$ samples contained withanolide B (Figure 8) (Tables 1 and 2).
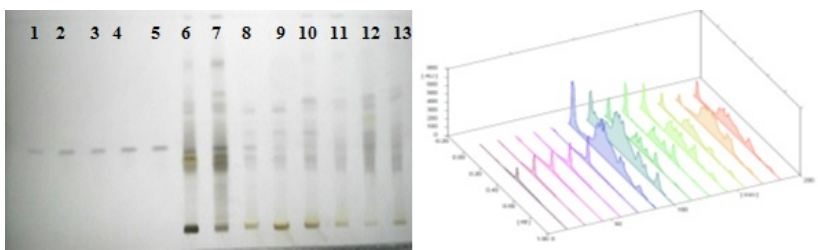

Figure 8 HPTLC fingerprint profile of withanolide B (Track 1-5) in diploid (Track 6-fruit; 7-stem; 8-leaf; root-9) and tetraploid (Track 10-fruit; 11-stem; 12-leaf; 13-root) cytotypes of $P$. angulata B) 3D view of densitogram at 530 $\mathrm{nm}$.

The amount of withanolide A and withanolide $B$ was found to be more in the tetraploid cytotype as compared to the diploid cytotype, significant at $\mathrm{P}<0.001$ (Table 1). Earlier, withanolide was isolated and purified from roots of Withania somnifera roots by using HPTL, HPLC and column chromatography [23].

Emodin: (1, 3, 8-trihydroxy-6-methylanthraquinone) is an anthaquinone. These are group of more than 170 natural compounds [24]. It is believed that the presence of hydroxyl groups in position 1 and 8 of the aromatic ring system is essential for the purgative action of this compound [25]. It has worldwide distribution with tropical, subtropical and temperate families of the plants. It is reported in 17 families, 28 genera and 94 species [26]. It was first described as "frangula-emodin" [27]. Originally it was reported in roots and bark of plants (Evans 1996) and recent research reported its presence in vegetative as well as reproductive parts of the plants [26]. It has many biological properties like antioxidant, diuretic, anti-tumour, antibacterial, anti-fungal antiviral and also acts as cardiac stimulant. Emodin is more common in three families Fabaceae (Cassia species), Polygonaceae (Rheum, Rumex \& Polygonum species) and Rhamnaceae (Rhamnus \& Ventilago species).
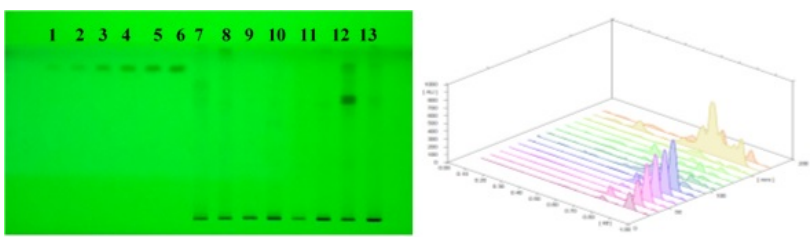

Figure 9 HPTLC fingerprint profile of emodin (Track 1-6) in diploid (Track 7-fruit; 8-stem; 9- leaf; root-10) and tetraploid (Track 10-fruit; 11-stem; 12-stem; 13-root) cytotypes of $P$. angulata B) 3D view of densitogram at 280 $\mathrm{nm}[28-30]$.

Presently, Toluene: Ethylacetae: Formic acid (10:8:0.8 v/v/v) were used to separate emodin in different plant parts of both the cytotypes. The $\mathrm{Rf}$ value of the compound was at 0.89
(Figure 9). Maximum amount of the reference compound was reported in leaf samples of the tetraploid cytotype (5.92 \pm $0.399 \mu \mathrm{g} / \mathrm{mg}$ DWE) followed by its root samples $(2.67 \pm 0.44$ $\mu \mathrm{g} / \mathrm{mg}$ DWE) respectively (Figure 9 ), (Tables 1 and 2 ).

The amount of emodin was found to be more in the tetraploid cytotype as compared to the diploid cytotype, significant at $\mathrm{P}<0.001$ (Table 1). Medina-Medrano et al., 2015 compared the phenolic composition of five species of Physalis. Some species of Physalis such as $P$. ixocarpa [31], P. peruviana [32], $P$. angulata [9], and $P$. alkekengi have been analyzed for their phenolic composition and antioxidant properties. Compounds like caffeic acid also have good antioxidant properties and also considered as an important part of the defense mechanism. Chlorogenic and caffeic acids are in vitro antioxidants and fight against diabetes and cardiovascular disease [33]. A significant pharmacological importance of their properties has been revealed by the presence of certain compounds of respective class such as lupeol for antidiabetic and anticancer activity, whereas â-sitosterol for antitumor activity [34].

Thus, the quantity of bioactive compounds varies with ploidy level as well as environmental conditions of the plant. Present study reveals that the tetraploid cytotype should be marked as the best chemotype with change in geographic distribution, for commercial as well as pharmaceutical purposes. It is concluded that the therapeutic action of this plant mainly lays in the tetraploid leaf sample as compared to the diploid cytotype.

Earlier similar studies to compare the mineral content [35] and fatty acid composition [36] in two cytotypes of $P$. angulata was carried out to mark a better chemotype for the plant species.

\section{Conclusion}

The existence of variation in bioactive compounds in the same species of relatively less explored medicinal plants at cytotype level and plant part basis indicates the need for making the better chemotypes and the exploitation for the different plant parts.

\section{Acknowledgments}

This study was funded by Department of Biotechnology (DBT), New Delhi, DBT-IPLS Project with reference number. The authors are also thankful to Head, Department of Botany, Punjabi University, Patiala, for all the necessary BT/PR 4548/NF/22/146/2012 laboratory facilities.

\section{References}

1. Santiaguillo HJF, Blas YS (2009) Aprovechamiento tradicional de las especies de Physalis en México. Rev Geogr Agr 43: 81-86.

2. Chang JC (2008) Antioxidative and hepatoprotective effects of Physalis peruviana extract against acetaminophen-induced liver injury in rats. Pharma Biol 46: 724-731. 
3. Abdia RD (2011) Aktivitas antihiperglikemik dari biomassa dan polisakarida ekstraseluler porphyridium cruentum sebagai inhibitor $\alpha$-glukosidase (Thesis). Institut Pertanian Bogor, Indonesia.

4. Susanti RF, Kurnia K, Vania A, Reynaldo IJ (2015) Total phenol, flavanoid and antioxidant activity of physalis angulata leaves extract by subcritical water extraction modern. Applied Science 9: 190-198.

5. Susanto A (2009) Flu babi: segala sesuatu yang perlu anda ketahui. Grasindo, Jakarta, Indonesia.

6. Budi SH (2008) Ragam and khasiat tanaman obat sehat alami dari halaman asri. Agromedia Pustaka, Jakarta, Indonesia.

7. Bastos GNT (2006) Antinociceptive effect of the aqueous extract obtained from roots of Physalis angulata L. on mice. J Ethnopharmacol 103: 241-245.

8. Lima MS, Evangelista AF, Dos Santos GGL, Ribeiro IM, Tomassini TCB, et al. (2014) Antinociceptive properties of physalins from Physalis angulata. J Nat Prod 77: 2397-2403.

9. Ismail N, Alam M (2001) A novel cytotoxic flavonoid glycoside from Physalis angulata. Fitoterapia 72: 676-679.

10. Ahmadu AA, Omonigho U (2013) Flavonoids from the leaves of Physalis angulata Linn. Afr J Pharm Res Dev 40-43.

11. Sarpate RV, Tupkari SV, Sarpate RV (2012) Quantification of lupeol isolated from strobilanthus callosus nees using validated high performance thin layer chromatography method. Int J Pharm Tech Res 4.

12. Hussain S, Fareed S, Ali M (2012) Simultaneous HPTLC-UV530 $\mathrm{nm}$ analysis and validation of bioactive lupeol and stigmasterol in Hygrophila auriculata (K. Schum) Heine. Asian Pac J Trop Biomed 612-617.

13. Leela A, Saraswathy P (2013) Quantification of pharmacologically active markers gallic acid, quercetin and lupeol from Acacia leucophloea willd flowers by HPTLC method 4: 146-150.

14. Hussain S, Fareed S, Ali M, Alam S, Rahman A, et al. (2014) Phytochemical investigation and simultaneous estimation of bioactive lupeol and stigmasterol in Abutilon indicum by validated HPTLC method. J Coastal Life Med 2: 394-401.

15. Selvaraj G, Kaliamurthi S, Ekambaram R, Thirugnanasambandan R (2014) Qualitative and quantitative phytochemical studies of Acanthus ilicifolius. Res J Phytochem 8: 133-138.

16. Saraf A, Shinde P (2016) HPTLC fingerprint profile, isolation and validation of marker compound lupeol in Derris heyneana (wight and arn) benth. Int J Pharm Bio Sci. 7: 714-721.

17. Bhattacharya SK, Satyan KS, Ghosal S (1997) Antioxidant activity of glycowithanolides from Withania somnifera. Indian J Exp Biol 35: 236-239.

18. Nayak P, Upadhyaya S (2009) HPTLC method for analysis of withaferin-A in Ashwagandha (Withania somnifera) Anubha Upadhyaya 22.

19. Supriya SJ, Tatke PA, Gabhe SY (2011) Development and validation of a novel hptlc method for simultaneous estimation of betasitosteroldglucoside and withaferin A. Int J Pharm Pharm Sci 2: 277-230.
20. Bhondave PD, Potawale SE, Gabhe SY, Harsulkar AM (2014) A rapid and simple high performance thin layer chromatographic method for simultaneous analysis of $\beta$-sitosterol-D-glucoside, gallic acid, withaferin $A$ and withanolide $A$ in Ashvagandharishta. Journal of Applied Pharmaceutical Science. 4: 82-87.

21. Patel JM (2008) A review of potential health benefits of flavonoids. Lethbridge Undergraduate Research Journal 3.

22. Sharma S, Sharma D, Raghuvanshi RK, Sharma RA, Chandrawat $P$ (2010) Cytological studies of Adhatoda L. species and Barleria L. species. The Bioscan 5: 67-70.

23. Sumithradevi S, Pradeepa D, Senthil K (2011) A simple method to purify withanolide a from the roots of Withania somnifera dunal. Int J Pharma Biosci 2: 231-236.

24. Thomson RH (1987) Naturally occurring quinines. III. Recent advances. Chapman \& Hall, London, UK.

25. Paneitz A, Westendorf J (1999) Anthranoid contents of rhubarb (Rheum undulatum L.) and other Rheum species and their toxicological relevance. Europ Food Res Technol 210: 97-101.

26. Izhaki I (2002) Emodin - a secondary metabolite with multiple ecological functions in higher plants. New Phytol 155: 205-217.

27. Kögl F, Postowsky JJ (1925) Untersuchungen üuber Pilzfarbstoffe. II. Über die Farbstaffe des blutroten Hautkorpfes (Dermocybe sanquinea Wulf.). Justus Liebigs Annalen der Chemie 444: 1-7.

28. Evans WC (1996) Treas and evans pharmacognosy, 4th edn. London, UK: WB Saunders Company.

29. Nandani D, Verma RN, Batra A (2013) Isolation and identification of quercetin and emodin from Cassia tora L. Annals of Phytomedicine 2: 96-104.

30. MedinaMedrano JR, AlmarazAbarca N, GonzalezElizondo MS, UribeSoto JN, GonzalezValdez LS, et al. (2015) Phenolic constituents and antioxidant properties of five wild species of Physalis (Solanaceae) Botanical studies 56: 24.

31. GonzalezValdez LS, HerreraArrieta Y (2015) Phenolic constituents and antioxidant properties of five wild species of Physalis (Solanaceae) Botanical studies 56: 24.

32. Rockenbach II, Rodrigues E, Cataneo C, Gonzaga LV, Lima A, et al. (2008) Phenolic acids and antioxidant activity of Physalis peruviana L. Alimentos e Nutrição 19: 271-276.

33. Morton LW, Caccetta RAA, Puddey IB, Croft KD (2000) Chemistry and biological effects of dietary phenolic compounds: relevance to cardiovascular disease. Clin Exp Pharmacol Physiol 27: 152-159.

34. Siddique HR, Saleem M (2011) Beneficial health effects of lupeol triterpene: A review of preclinical studies. Life Sci J 88: 285-293.

35. Ramanpreet, Gupta RC, Pradhan SK (2017) Elemental analysis and biological studies of Physalis angulata L. by using Wave length dispersive $\mathrm{X}$-ray fluorescence technique, WDXRF, from Rajasthan. Asian J Pharm Clin Res 10: 220-224.

36. Ramanpreet, Gupta RC (2017) Fatty acid profiling in diploid $(n=12)$ and tetraploid cytotypes $(n=24)$ of Physalis angulata from Rajasthan by gas chromatography. Int J Pharm Sci Res 8: 3458-3462. 